\title{
Hubungan Disiplin, Kompensasi Dengan Kinerja Pada Pusat Pemanfaatan Penginderaan Jauh Lapan, JakartaTimur
}

\author{
Dedy Syahyuni \\ Universitas Bina Sarana Informatika \\ e-mail: dedy.ddn@bsi.ac.id

\begin{tabular}{ccc}
\hline Diterima & Direvisi & Disetujui \\
$19-12-2019$ & $23-01-2020$ & $24-02-2020$ \\
\hline
\end{tabular}

\begin{abstract}
Abstrak - Dalam setiap organisasi baik swasta atau pemerintahan, salah satu perhatian dari bagian atau divisi manajemen sumber daya manusia adalah eningkatan kinerja karyawannya. Hal ini terus diperhatikan dan ditingkatkan sehubungan dengan semakin tingginya tuntutan dari masyatakat. Peningkatan laba atau efektifikas dan efisiensi kerja di perusahaan swasta atau peningkatan mutu pelayanan dari organisasi pemerintah terus diperhatikan oleh stake holder masing masing. Telah banyak penelitian dan tulisan ilmiah yang membahas permaslahan kinerja akan tetapi tulisan ini mencoba membahas bagaimana sebuah organisasi pemerintah meningkatkan dan mempertahankan kinerja dari para karyawanannya. Biasanya kinerja banyak dipengaruhi oleh motivasi dan pelatihan akan tetapi tulisan ini mencoba membahas cara organisasi pemerintah dalam hal ini Pusat Pemanfaatan Penginderaan Jauh (Lapan), JakartaTimur dalam upaya peningkatan variabel kinerja karyawan dan hubunganya dengan variabel kompensasi dan variabel disiplin kerja. Sebagai responden pada tulisan ini adalah para karyawan yang bekerja Pada Pusat Pemanfaatan Penginderaan Jauh (Lapan), Jakarta Timur. Tulisan ini menggunakan metode kuantitatif deskrptif dimana mencoba untuk melihat hubungan diantara variabel yaitu variabel Disiplin kerja, kompensasi dan hubungannya dengan kinerja karyawan.
\end{abstract}

Kata Kunci: Disiplin, Kompensasi dan kinerja

\begin{abstract}
In any organization, whether private or government, one concern from the division or division of human resource management is the improvement of the performance of its employees. This continues to be noted and improved in line with the increasing demands of the community. Increasing profits or effectiveness and work efficiency in private companies or improving the quality of service from government organizations continue to be considered by their respective stakeholders. There have been many studies and scientific papers that discuss performance issues but this paper tries to discuss how a government organization improves and maintains the performance of its employees. Usually performance is much influenced by motivation and training but this paper tries to discuss the way government organizations in this case the Center for Remote Sensing Utilization (Lapan), East Jakarta in an effort to improve employee performance variables and their relationship with compensation variables and work discipline variables. Respondents in this paper are employees who work at the Center for Remote Sensing Utilization (Lapan), East Jakarta. This paper uses descriptive quantitative methods which try to see the relationship between variables, namely the variable Work discipline, compensation and its relationship with employee performance.
\end{abstract}

Key word : Dicipline, Compensation, Job Performance

\section{PENDAHULUAN}

Disiplin kerja adalah suatu tingkatan kehadiran para karyawan dalam organisasi, bagaimana karyawan menataai semua tata aturan yang ada dalam organisasi, sebuah pola kerja yang harus ditaati oleh para karyawan dan sejenisnya.

Dari disiplin kerja, para pekerja memberikan tugasnya dengan baik dan disiplin kerja merupakan salah satu tolok ukur kesetiaan para karyawan pada organisasi atau perusahaan karena itu disiplin kerja merupakan perihal yang sangat penting bagi jalannya perusahaan bisnis atau suatu organisasi.

Selanjutnya kompensasi adalah balas jadi dari apa yang sudah karyawan berikan kepada perusahaan atau organisasi. Tinggi rendahnya dari kompensasi yang diberikan perusahaan tergantung dari seberapa banyak kontribusi karyawan kepada perusahaan atau organisasi. Selain dari itu banyak sedikitnya kompensasi yang diberikan tergantung dari seberapa bagus karyawan dalam bekerja, misalnya baiknya 
kualitas pekerjaan menambah sedikit banyaknya kompensasi.

Oleh karena itu terkadang ada yang berpendapat bahwa bila disiplin kerja baik maka kompensasi juga baik. Hal ini bukan hal yang salah akan tetapi tidak seluruhnya benar karena besr kecilnya kompensasi tergantnug pada variabel yang lain seperti kompetensi, motivasi dan lainnya.

Akan tetapi apakah yang mungkin dipengaruhi oleh disiplin kerja dan kompensasi dalam pekerjaan para karyawan. Banayak penelitian yang telah dilakukan untuk membahs ini akan tetapi dalam hal ini penulis mencoba melihat hubungan antara disiplin, kompensasi dengan kinerja karyawan. Untuk membahas lebih baik, berikut adalah paparan teori akan ketiga variabel tersebut sebelum dihitung dengan bantuan excel dan SPSS Versi 21.

\section{Disiplin}

Menurut pendapat dari Singodimedjo (Sutrisno, 2016) dinyatakan bahwa "disiplin adalah sikap kesediaan dan kerelaan seseorang untuk memtuhi dan menaati norma-norma peraturan yang berlaku disekitarnya. Disiplin karyawan yang baik akan mempercepat tujuan perusahaan, sedangkan disiplin yang merosot akan menjadi penghalang dan memperlambat pencapaian tujuan perusahaan.”

Selain dari itu menurut Siagian (Sutrisno, 2016) tingkat disiplin kerja yang baik atau yang tinggi dapat tercermin pada keadaan, yaitu :

1. Adanya rasa keperdulian yang tinggi dari karyawan terhadap pencapaian tujuan oraganisasi.

2. Semangat dan atau gairah kerja juga insiatif dari para karyawan dalam melakukan pekerjaannya.

3. Rasa tanggung jawab yang tinggi dari para karyawan dalam melaksanakan tugas dengan sebaik-baiknya.

4. Rasa memiliki dan rasa solidaritas yang tinggi dikalangan para karyawan didalam organisasi.

5. Semakin baiknya tinggat efisiensi kerja dan juga produktivitas kerja dari para karyawan.

Menurut (Sutrisno, 2016) keadaaan yang teratur adalah ciri utama organisasi dan disiplin kerja adalah salah satu cara untuk memelihara keteraturan dalam tersebut. Tujuan utama dari adalah untuk meningkatkan atau mempertahankan efisiensi seoptimal mungkin dengan cara mencegah inefisiensi dari penggunaan enagi dan waktu. Disiplin kerja mencoba meminimalisasi kesalahan dan keteledoran yang disebabkan oleh kurang perhatian, ketidakmampuan dan juga keterlambatan. Disiplin kerja berusaha untuk mencegah pekerjaan yang lambat atau terlalu dini mengakhiri pekerjaan yang disebabkan oleh keterlambatan prosedur atau kemalasan karyawan.

Menurut Siagian dalam (Sutrisno, 2016) Bentuk dari pelanasaan disiplin yang baik dan benar akan tercermin pada adanya suasana, yaitu :
1. Rasa keperdulian yang tinggi dari karyawan terhadap pencapaian dari tujuan perusahaan.

2. Semangat dan gairah kerja juga insiatif yang tinggi dari para karyawan dalam melakukan pekerjaan.

3. Rasa tanggung jawab yang besar dari para karyawan dalam melaksanakan tugas dengan sebaik-baiknya.

4. Rasa memiliki dan rasa solidaritas yang semakin tinggi dikalangan para karyawan.

5. Adanya peningkatan efisiensi dan produktivitas kerja dari para karyawan.

Menurut (Hasibuan, 2016) kedisiplinan karyawan adalah suatu kesadaran dan kesediaan dari seseorang untuk mentaati peraturan perusahaan juga norma-norma sosial yang berlaku dalam lingkungannya. Kesadaran merupakan sikap seseorang yang secara suka rela dan tanpa paksaan dalam mentaati semua peraturan dan juga sadar akan tugas termasuk tanggung jawabnya. Lebih lanjut Menurut (Hasibuan, 2016) Kesediaan dalam disiplin kerja adalah suatu wujud dari sikap tingkah laku dan perbuatan dari karyawan yang sesuai dengan peraturan yang dibuat oleh perusahaan baik peraturan tertulis maupun peraturan yang tidak tertulis .

\section{Kompensasi}

Menurut Andrew E Sikula dalam (Mangkunegara, 2013) yang dimaksud dengan kompensasi adalah sesuatu yang dihitung sebagai suatu yang sama. Dalam hubungannya dengan MSDM, hadiah atau pemberian yang bersifat keuangan, dalam hal ini balsa jasa atau kompensasi yang diberikan kepada para karyawan sebagai bentuk dari penghormatan dari pekerjaan yang mereka berikan. Aturan dan ketentuan dari bentuk pemberian upah dan gaji digunakan sebagai alat mengelola pemberian keuangan antara pimpinan dan pegawainya.

Menurut (Suwatno, 2016) sebuah perusahaan harus dapat menetapkan kegiatan kompensasi yang didasari oleh pertimbangan peraturan pemerintah, memperhatikan kemampuan perusahaan dan lingkungannya, sehingga menjamin kepuasan kerja karyawan yang pada akhirnya para karyawan dapat termotivasi dalam bekerja.

1. Asas Keadilan

Pemberian kompensasi dapat merubah perilaku dari para karyawan dalam perusahaan dan organisasi. Pemberian dari kompensasi yang tidak didasari pada asas keadilan akan menciptakan kondisi kerja karyawan yang tidak baik. Azas keadilan adalah suatu kondisi imbalan bagi para karyawan yang melaksanakan tugas dan tanggung jawabnya dengan beban yang sama. Dapat dikatakan dalam arti lain, bahwa kompensasi bagi karyawan di suatu yang sama atau dengan besar bobot yang sama, relatif memberikan dampak pada besar kompensasi yang 
sama yang didapatkan olh setiap karyawan. Sehingga dengan dengn terwujudnya asas keadilan dapat menciptakan lingkungan kerja yang ideal, semangat kerja, disiplin, loyalitas kerja, dan stabilitas dari karyawan akan tercipta dengan lebih baik.

2. Asas Kelayakan dan Kewajaran

Besarnya nilai Kompensasi yang didapatkan oleh para karyawan harus dapat dipastikan sudah memenuhi semua hal yang mereka butuhkan dalam kehidupan mereka. Sehingga berapa jumlah uang yang dapatkan akan mencerminkan status, kemampuan dan juga penilaian karyawan pada perusahaan. Sebagai salah satu ukuran yang dipakai dalam penentuan kompensasi ini adalah standar Upah Minimun Regional (UMR). Kompensasi dapat dikatakan cukup apabila besaran kompensasi sudah mempertimbangkan harus mempertimbangkan faktor seperti prestasi kerja karyawan, strata pendidikan, macam dari pekerjaan, risiko yang meungkin timbul dalam pekerjaan, besarnya tanggung jawab yang diemban oleh karyawan, posisidan lainnya. Seorang Manajer pada bagian SDM harus dapat menelaah dan juga menyesuaikan besarnya nilai kompensasi yang sebaiknya didapatkan oleh para karyawan perusahaan dah hal in harus disesuaikan dengan perubahan yang terjadi dialam lingkungan perusahaan termasuk ketentuan pemerintah.

Besarnya kompensasi yang baik harus memberikan efek positif bagi para karyawan perusahaan dan juga bagi kemajuan perusahaan. Tujuan kompensasi menurut (Suwatno, 2016) adalah :

1. Komitmen dalam bekerja sama

2. Kepuasan karyawan dalam bekerja

3. Pengadaan sumberdaya yang tepat

4. Semangat kerja

5. Terciptanya asas keadilan

6. Disiplin kerja para karyawan

7. Pemaksimalan fungsi dari Serikat kerja

8. Pengaruh dari kebijakan peraturan pemerintah Menurut (Suwatno, 2016), Kompensasi harus memberi dampak positif bagi karyawannya berikut penjelasannya.

1. Dengan adanya kompensasi yang baik akan terjalin suatu hubungan yang baik dan ideal antara karyawan dengan perusahaan, hubungnan yang saling terhubung dan saling membutuhkan.

2. Setiap pekerjaan dan pencapaikan target perusahaan yang dilakukan oleh para karyawan dilakukan dengan seoptimal miungkin sehingga efisiensi dan efektifitas tinggi.

3. Pencarian dari karyawan baru akan berjalan dengan baik dan benar bila sistem kompensasi dilaksanakan dengan baik.

4. Setiap karyawan yang bekerja akan mendapatkan efek yang baik bila mereka memahami bahwa Kompensasi diberikan dengan layak.
5. Kompensasi pekerjaann yang baik akan memberikan kepastian terjadinya keadilan di dalam organisasi.

6. Disiplinan dalam bekerja akan tercipta bila kompensasi telah dirasa memadai.

7. Keberadaan serikat buruh atau serikat pekerja dalam perusahaan dapat dimaksimalkan sebagai mitra bagi manajemen.

8. Peratuan pemerintahan dapat menjamin penghidupan yang layak bagi masyarakat dalam hal ini para pekerja.

\section{Kinerja}

Menurut (Mangkunegara, 2013) kata kinerja berasal dari akar kata Job Performance atau disebut juga deganan Actual Performance atau diartikan sebagai prestasi kerja atau terkadang disebut juga degan prestasi pada dasarnya adalah keadaaan yang sesungguhnya yang telah diraih oleh seorang pekerja. Pengertian dari kinerja adalah suatu hasil atau manfaat kerja secara jumlah dan mutu yang dikerjakan oleh karyawan dalam menunaikan tugas dan tanggung jawabnya sesuai dengan penugsasan yang dilimpahkan perusahaan.

Menurut Harmani Pasolong (Fahmi, 2016) Kinerja karyawan memiliki beberapa bagian, yaitu :

1. Hasil pekerjaan yang telah diselesaikan oleh pekerja dan atau timnnya daalam sebuah lingkungan kerja.

2. Peraturan yang dibuat untuk menjalankan fungsi dari tugas yang diemban oleh karyawan dalam melaksanakan tugasnya.

3. Para pekerja dalam melaskanakan tugas dan tanggung jawabnya harus sesuai dengan aturan dan ketentuan perusahaan.

4. Semua tugas dan tangggung jawab pekerjaan tidak bertentangan dengan aturan moral dan atau etika yang berlaku secara umum dimasyarakat.

Menurut Wirawan (Pramularso, 2017) "Kinerja adalah keluaran yang dihasilkan oleh fungsifungsi atau indikator-indikator suatu pekerjaan atau suatu profesi dalam waktu tertentu”. Lebih lanjut menurut Wirawan dalam (Pramularso, 2017) kinerja dari karyawan secara operasional secara umum bisa dibagi menjadi tiga bagian : pertama hasil kerja, kedua perilaku kerja dan ketiga sifat pribadi para pekerja yang berhubungan dengan pekerjaannya.

Menurut Sudarmanto dalam (Syahyuni, 2018) menyimpulkan bahwa : suatu organisasi yang sukses dan efektif dalam pencapaia tujuannya merupakan suatu organisasi yang dengan para pekerja yang ada didalamnya memiliki tingkat kinerja yang tinggi. Organisasi yang sukses akan ditopang oleh sumber daya manusia yang baik dan berkualitas tinggi. Banyak contoh kasus dari beberapa organisasi yang dapat berhasil dan juga efektif dalam pencapaian tujuan karena perusahaan atau organisasi ditopang oleh adanya tngkat kinerja karyawan yang tinggi. Sebaliknya, tidak sedikit pula peruahaan yang 
mengalami gagal bahkan kebangkrutan karena kinerja karyawan yang buruk. Oleh karena itu, harus ada kesesuaian antara keberhasilan organisasi atau terkadang disebut juga dengan kinerja organisasi dengan kinerja dari para karyawan didalam perusahaan.

Menurut Dessler dalam (Syahyuni, 2018)

Terdapat 6 indikator dari kinerja karyawan:

1. Mutu kerja adalah ketepatan, ketelitian, dan tingkat dapat diterimanya pekerjaan untuk dapat dilaksanakan.

2. Produktivitas dilihat dari mutu dan efisiensi kerja yang selesaikan oleh para karyawan dalam waktu tertentu. I

3. Informasi dan juga pengetahuan atas pekerjaan dan tugas adalah kemampuan praktis dan teknik juga informasi dalam pekerjaan dapat diakses degnan baik.

4. Para karyawan di percaya dapat melaksanakan tugas dan tanggung jawab dengan penyelesaian pekerjaannya.

5. Adanya jumlah yang memadai dari waktu pengerjaan pekrjaan, waktu istirahat / jam makan, dan keseluruhan catatan kehadiran, sehingga para karyawan mendapatkan hak dan kewajibannya secara propossional.

6. Para pekerja mendapatkan kebebasan dalam mengerjakan pekerjaan tanpa harus didampingi oleh pengawas atau supervisor.

\section{Validitas dan Reliabilitas}

Menurut Priyatno dalam (Pramularso, 2017) Uji dari validitas item dipergunakan untuk mengambarkan seberapa tepat suatu bahan penelitian Suatu Item dapat dinyatakan valid apabila ditemukan korelasi atau hubungan dengan nilai total. Pengujian dari validitas item dalam aplikasi spss dapat menggunakan 2 buah cara analisa, Korelasi Pearson atau disebut juga dengan Corrected item Total Correlation. Dalam teknik uji dari validitas item dengan korelasi pearson, dapat dilakukan dengan cara mengkorelasi nilai item dengan nilai dari total item, kemudian pengujian atas signifikansi dapat dilakukan dengan menilai criteria $r$ tabel pada tingkat ukuran signifikansi 0,05 dengan uji 2 sisi. Jika nilai didapatkan positif dan $r$ hitung lebih besar dari nilai $r$ tabel, maka item dapat dinyatakan sebagai nilai valid (demikian pula bila hasil didapatkan sebaliknya).

Lebih lanjut Priyatno dalam Pramularso, Uji atas reliabilitas adalah uji untuk melihat konsistensi dari alat ukur yang biasanya menggunakan koesioner Tanya jawab yang dibagiakan kepada responden. cara yang sering dipakai dalam penelitian ini adalah mengguakan skala rentangan atau lazim disebut dengan Cronboach Alpha. Uji reliabilitas adalah kelanjutan dari uji validitas dimana dalam pengujian ini item yang masuk dalam pengujian adalah item item yang masuk pengujian adalah item yang valid saja.
Dalam tulisan ini penulis menggunakan teori dari Siagian dalam Sutrisno untuk variabel disiplin, teori Susilo Martoyo dalam teori Badriyah untuk variabel kompensasi dan teori dari Hermani Pasolong dalam Fahmi untuk variabel Kinerja

\section{METODOLOGI PENELITIAN}

Penelitian ini penulis mengunakan metode kuantitatif deskriptif. Metode ini dilakukan dengan cara dimana semua variabel dipertemukan dalam sebuah hitungan statistik. Perhitungan menggunakan bantuan MS Excel dan SPSS atau kepanjangan dari Statistical Product and Service Solution dan tulisan ini menggunakan Versi 21. Selain dari itu tulisan ini menggunakan bberapa referensi dari beberapa buku yang berhubugnan dengan judul dan beberapa jurnal ilmiah yang juga sesuai dengan judul sebagai dasar teori sehinga penelitian dapat memiliki dasar teori yang kuat.

Metode pengambilan sample menggnakan metode sample jenuh dimana seluruh karyawan pada bagian tersebut dijadikan sample. Sedangkan dalam pembuatan kuisioner menggunakan teori dari beberapa ahli.

\section{HASIL DAN PEMBAHASAN}

Dari hasil perhitungan yang telah dihitung dengan bantuan Microft Soft Excel dan SPSS versi 21 maka didapatkan hasil seperti berikut. Dalam perhitungan validitas maka dapat terlihat dalam tabel 1 dibawah ini

\section{Tabel 1}

\begin{tabular}{rlll}
\hline \multicolumn{4}{c}{ Validitas Disiplin Kerja } \\
\hline no & r tabel & r hitung & valititas \\
\hline $\mathbf{1}$ & 0,279 & 0,625 & valid \\
\hline $\mathbf{2}$ & 0,279 & 0,492 & valid \\
\hline $\mathbf{3}$ & 0,279 & 0,503 & valid \\
\hline $\mathbf{4}$ & 0,279 & 0,650 & valid \\
\hline $\mathbf{5}$ & 0,279 & 0,532 & valid \\
\hline $\mathbf{6}$ & 0,279 & 0,557 & valid \\
\hline $\mathbf{7}$ & 0,279 & 0,620 & valid \\
\hline $\mathbf{8}$ & 0,279 & 0,397 & valid \\
\hline $\mathbf{9}$ & 0,279 & 0,487 & valid \\
\hline $\mathbf{1 0}$ & 0,279 & 0,497 & valid \\
\hline
\end{tabular}

Dapat terlihat dari hasil perhitungan validitas ditemukan bahwa semua item dari kuisioner variabel disiplin kerja memiliki tingkat validitas yang baik (semua valid). 


\begin{tabular}{rlll}
\hline \multicolumn{4}{c}{ Tabel 2 } \\
\hline \multicolumn{4}{c}{ Validitas Kompensasi } \\
\hline no & r tabel & r hitung & valititas \\
\hline $\mathbf{1}$ & 0,279 & 0,431 & valid \\
\hline $\mathbf{2}$ & 0,279 & 0,486 & valid \\
\hline $\mathbf{3}$ & 0,279 & 0,409 & valid \\
\hline $\mathbf{4}$ & 0,279 & 0,328 & valid \\
\hline $\mathbf{5}$ & 0,279 & 0,383 & valid \\
\hline $\mathbf{6}$ & 0,279 & 0,292 & valid \\
\hline $\mathbf{7}$ & 0,279 & 0,598 & valid \\
\hline $\mathbf{8}$ & 0,279 & 0,570 & valid \\
\hline
\end{tabular}

Sedangkan dalam uji validitas untuk variabel kompensasi ditemukan bahwa hasil uji validitas untuk semua item pertanyaan adalah valid, seperti terlihat pada tabel 2 diatas.

\section{Tabel 3}

\begin{tabular}{rlll}
\hline \multicolumn{3}{c}{ Validitas Kinerja } \\
\hline no & r tabel & r hitung & valititas \\
\hline $\mathbf{1}$ & 0,279 & 0,463 & valid \\
\hline $\mathbf{2}$ & 0,279 & 0,724 & valid \\
\hline $\mathbf{3}$ & 0,279 & 0,4436 & valid \\
\hline $\mathbf{4}$ & 0,279 & 0,647 & valid \\
\hline $\mathbf{5}$ & 0,279 & 0,679 & valid \\
\hline $\mathbf{6}$ & 0,279 & 0,500 & valid \\
\hline $\mathbf{7}$ & 0,279 & 0,335 & valid \\
\hline $\mathbf{8}$ & 0,279 & 0,329 & valid
\end{tabular}

Dari hasil uji validitas variebel kinerja sebagai variabel terikat dalam tulisan in didapatkan hasil bahwa semua item dari pertanyaan dinyatakan valid karena melewati batas nilai $\mathrm{r}$ tabel.

Dalam perhitungan reabilitas atas tiga variabel tulisan ini maka dapat terlihat dalam beberapa tabel berikut.

Tabel 4

Reliability Statistics

\begin{tabular}{|r|r|}
\hline Cronbach's Alpha & N of Items \\
\hline .705 & 10 \\
\hline
\end{tabular}

Hasil uji reabiltas untuk variabel disiplin adalah 0,705 yang artinya tingkat reabiltasnya kuat.

Tabel 5

Reliability Statistics

\begin{tabular}{|r|r|}
\hline Cronbach's Alpha & N of Items \\
\hline .403 & \\
\hline
\end{tabular}

Dari hasil perhitungan uji reabilitas yang menggunakan SPSS untuk variabel kompensai didaptkan hasil cukup reabel

Tabel 6

Reliability Statistics

\begin{tabular}{|r|r|}
\hline Cronbach's Alpha & N of Items \\
\hline .623 & \\
\hline
\end{tabular}

Sedangkan untuk variabel terikat dalam tulisan ini maka didapatkan hasil reabilitas yang kuat. Dalam uji normalitas atau uji untuk menegtahui seberapa baik tingkat kenormalan data maka didapatkan hasil :

Tabel 7

One-Sample Kolmogorov-Smirnov Test

\begin{tabular}{|ll|r|}
\hline & Mean & $\begin{array}{r}\text { Unstanda } \\
\text { rdized } \\
\text { Residual }\end{array}$ \\
\hline $\mathrm{N}$ & Std. & 50 \\
Normal & Deviation & 1.423 \\
Parameters ${ }^{a, b}$ & Absolute & 0.228 \\
Most Extreme & Positive & 0.228 \\
Differences & Negative & -0.134 \\
Kolmogorov-Smirnov Z & 1.613 \\
Asymp. Sig. (2-tailed) & 0.011 \\
\hline
\end{tabular}

a. Test distribution is Normal.

b. Calculated from data.

Sedangkan untuk perhitungan uji multikolinieritas didapatkan hasil sebagai berikut :

Tabel 8 Multikolinieritas

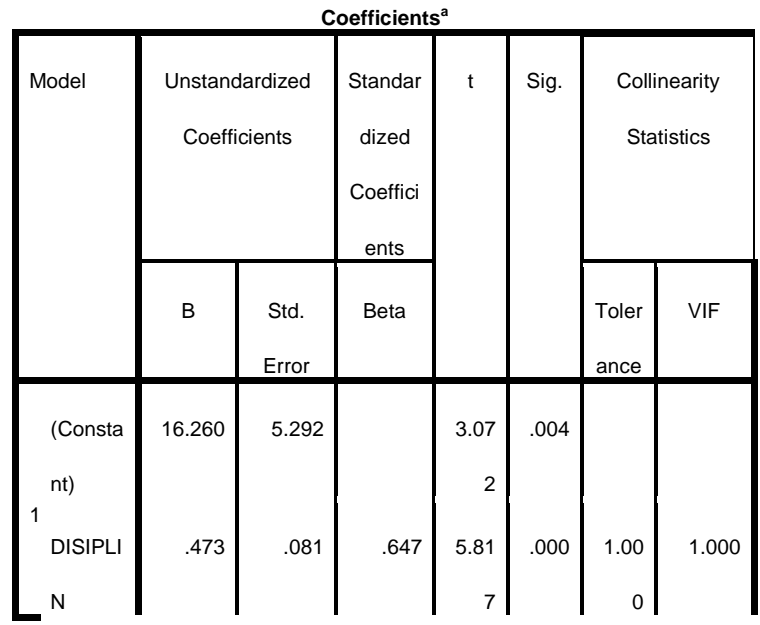




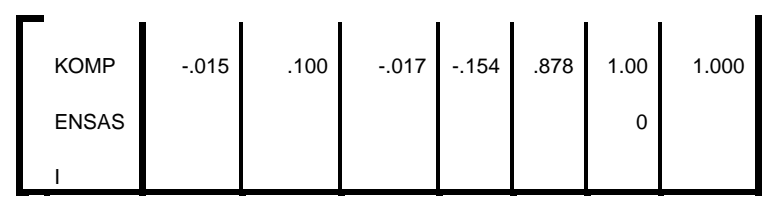

a. Dependent Variable: KNERJA

Berikutnya dalam menghitung heterokedaksitas atau untuk mengetahui apak ada keraguan atas data yang digunakan maka dapat terlihat dari tabel berikut.

\section{Tabel 8 Heterokedaksitas}

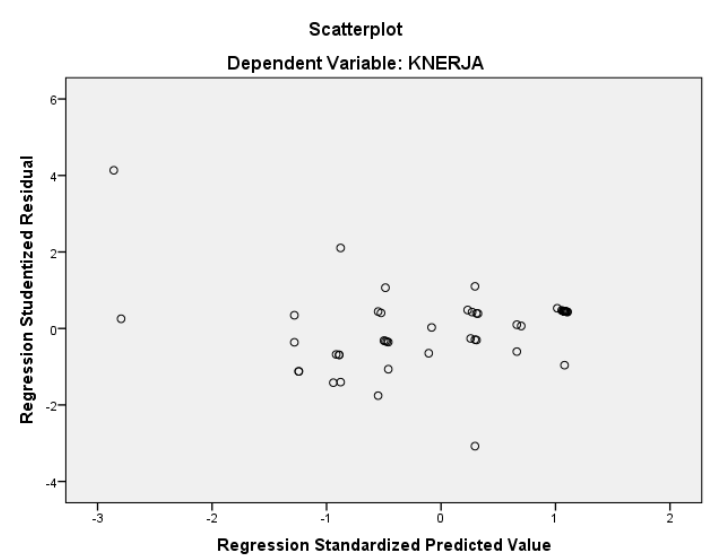

Dari tabel diatas dapat terlihat bahwa gambar menyerbar, diantara nilai nol dan tidak terbentuk berpola dan tidak berpola bergelombang diman artinya tidak terdapat kerugan atas data yang dipakai. Berikutnya setelah kita menghitung uji kalsik maka kita lakukan uji korelasi dan determinasi, adapuan hasil dari uji korelasi dan determinasi adalah sebagai berikut.

Tabel 9 Korelasi

\begin{tabular}{|c|c|c|c|c|}
\hline \multicolumn{5}{|c|}{ Correlations } \\
\hline & & $\begin{array}{c}\text { DISIPLI } \\
\mathrm{N}\end{array}$ & $\begin{array}{c}\text { KOMPEN } \\
\text { SASI }\end{array}$ & $\begin{array}{c}\text { KNERJ } \\
\text { A }\end{array}$ \\
\hline \multirow{6}{*}{ DISIPLIN } & Pearson & 1 & -019 & $647^{* *}$ \\
\hline & & & & \\
\hline & Correlation & & & \\
\hline & Sig. (2-tailed) & & .894 & .000 \\
\hline & $\mathrm{N}$ & 50 & 50 & 50 \\
\hline & Pearson & -.019 & 1 & -.030 \\
\hline \multirow{3}{*}{$\begin{array}{l}\text { KOMPEN } \\
\text { SASI }\end{array}$} & Correlation & & & \\
\hline & Sig. (2-tailed) & .894 & & .838 \\
\hline & $\mathrm{N}$ & 50 & 50 & 50 \\
\hline \multirow{3}{*}{ KNERJA } & Pearson & $.647^{* \star}$ & -.030 & 1 \\
\hline & Correlation & & & \\
\hline & Sig. (2-tailed) & .000 & .838 & \\
\hline
\end{tabular}

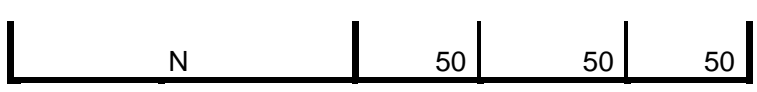

**. Correlation is significant at the 0.01 level (2tailed).

Tabel 10 Determinasi

\begin{tabular}{|l|c|r|r|r|}
\multicolumn{5}{|c|}{ Model Summary } \\
\hline $\begin{array}{l}\text { Mo } \\
\text { del }\end{array}$ & $R$ & $\begin{array}{c}\text { R } \\
\text { Square }\end{array}$ & $\begin{array}{r}\text { Adjusted } \\
\text { R Square }\end{array}$ & $\begin{array}{r}\text { Std. Error of } \\
\text { the Estimate }\end{array}$ \\
\hline 1 & $.647^{\mathrm{a}}$ & .419 & .394 & 1.453 \\
\hline
\end{tabular}

a. Predictors: (Constant), KOMPENSASI, DISIPLIN

b. Dependent Variable: KiNERJA

Dapat terlihat bahwa hasil uji korelasi ditemukan bahwa tingkat korelasi (R) adalah 0,647 yang artinya kedaua variabel bebas berhubugnan kuat dengan variabel kinerja. Sedangkan deterimasi didapatkan dari nilai R Square sebesar 0.419 atau dapat dikatakan bahwa variabel disiplin dan kompensasi memberikan sumbangan sebesar 41,9\% atas terjadinya variabel kinerja,

Hal ini sejalan dengan penelitian sebelumnya dari Pramularso, yang menyatakan bahwa disiplin kerja mempengaruhi kinerja. Menurut (Pramularso, 2017) hasil perhitungan tabel dapat diketahui besarnya koefisien korelasi ( $R$ ) sebesar 0,499 yang berarti terdapat hubungan antara disiplin kerja karyawan dengan variabel kinerja karyawan pada Hotel Cipta, Pancoran di Jakarta Selatan dan hubungan tersebut adalah cukup kuat. Sedangkan pada uji Koefisien determinasi ( $\mathrm{R}$ Square) sebesar 0,249, artinya kontribusi atau disiplin kerja terhadap kinerja karyawan Cipta Hotel, Pancoran Jakarta Selatan sebesar 24,9\%, sedangkan sisanya sebesar $75,1 \%$ adalah sumbangan dari faktor lain selain dari faktor disiplin kerja karyawan dan untuk itu diperlukan penelitian lebih lanjut untuk mengetahui lebih jauh.

Akan tetapi dalam penelitian yang lain didapatkan hasil bahwa apabila kinerja terjadi dengan baik maka akan tercipta promosi jabatan. Lebih lanjut (Syahyuni, 2018) menyatakan Dari hasil uji determinasi diatas didapatkan kesimpulan bahwa kinerja memberikan sumbangan sebanyak 53,6 persen terhadap promosi jabatan. Sedangkan sisa nya atau 46,4 persen dipengaruhi oleh variable atau faktor lain.

Jadi apabila para karyawan ingin terjadi promosi jabatan maka yang mereka harus lakukan adalah disilin dalam bekerja sehingga terjadi kinerja lalu akhirnya terjadi promosi.

Selanjutnya dari perhitungan yang menggnakan aplkasi SPSS, maka tabel Anova didapatkan hasil sebagaimana berikut: 
Tabel 11 Anova

ANOVAa

\begin{tabular}{|c|r|r|r|r|r|}
\hline Model & $\begin{array}{c}\text { Sum of } \\
\text { Squares }\end{array}$ & $\mathrm{df}$ & $\begin{array}{c}\text { Mean } \\
\text { Squar } \\
\mathrm{e}\end{array}$ & $\mathrm{F}$ & Sig. \\
\hline $\begin{array}{c}\text { Regre } \\
\text { ssion }\end{array}$ & 71.596 & 2 & 35.798 & 16.957 & $.000^{\mathrm{b}}$ \\
$\begin{array}{l}\text { Residu } \\
\text { al }\end{array}$ & 99.224 & 47 & 2.111 & & \\
Total & 170.820 & 49 & & & \\
\hline
\end{tabular}

a. Dependent Variable: KNERJA

b. Predictors: (Constant), KOMPENSASI, DISIPLIN

Untuk menegtahui uji determinasi maka dapat dilihat dari tabel berikut ini

Tabel 12 Determinasi

\section{Coefficients $^{a}$}

\begin{tabular}{|l|r|r|r|r|l|}
\hline Model & \multicolumn{2}{|c|}{$\begin{array}{r}\text { Unstandardiz } \\
\text { ed } \\
\text { Coefficients }\end{array}$} & $\begin{array}{r}\text { Standar } \\
\text { dized } \\
\text { Coefficie } \\
\text { nts }\end{array}$ & Sig. & \\
\cline { 2 - 4 } & B & $\begin{array}{r}\text { Std. } \\
\text { Error }\end{array}$ & Beta & & \\
\hline $\begin{array}{l}\text { (Const } \\
\text { ant) }\end{array}$ & 16.260 & 5.29 & & 3.0 & .004 \\
DISIP & .473 & .081 & .647 & 5.8 & .000 \\
LIN & & & & 17 & \\
KOMP & -.015 & .100 & -.017 & -878 \\
ENSA & & & & .15 & \\
SI & & & & 4 & \\
\hline
\end{tabular}

a. Dependent Variable: KNERJA

Dapat dilihat bahwa dari tabel diatas maka diperoleh persamaan baru dari perhitungan determinasi sebagai ana berikut :

$\mathrm{Y}=\mathrm{A}+\mathrm{bX} 1+\mathrm{X} 2$

$Y=16.260+0,473+-0,015$

\section{KESIMPULAN}

Dari hasil pembahasan dan perhitungan dengan bantuan MS excel dan SPSS versi 21 maka ditemukan bahwa ada hubungan anatara ketiga variebl sesuai dengan dugaan awal penulis. Ada hubungan yang cukup kuat diantara variebal disiplin kerja dan kompensasi terhadap kinerja karyawan pada Pusat Pemanfaatan Penginderaan Jauh Lapan, JakartaTimur hal ini terihat dari hasil perhitungan pada bagian sebelumnya selain dari itu adanya kontribusi (determiasi) dari terjadinya kinerja karyawan dari variable disiplin dan kompensasi akan tetapi perlu dilakukan penelitian lanjutan untuk mengatahu lebih jauh atas variabel lain yang diperkiraan mempengaruhi kinerja selain dari variabel disiplin dan kompensasi.

\section{REFERENSI}

Fahmi, I. (2016). Perilaku Organisasi. Bandung: Alfabeta.

Hasibuan, M. (2016). Manajemen Sumber Daya Manusia. Jakarta: Bumi Aksara.

Mangkunegara, A. P. (2013). Manajemen Sumber Daya Manusia Perusahaan. Bandung: Remaja Rosdakarya.

Pramularso, E. Y. (2017). Pengaruh Disiplin Kerja Terhadap Kinerja Karyawan Cipta Hotel Pancoran Jakarta Selatan. Widya Cipta - Jurnal Sekretari Dan Manajemen, 1(2), 171-178. Retrieved

from https://ejournal.bsi.ac.id/ejurnal/index.php/wid yacipta/article/view/2220

Sutrisno, E. (2016). Manajemen Sumber Daya Manusia (8th ed.). Jakarta: Kencana.

Suwatno. (2016). Manajemen Sumber Daya Manusia. Bandung: Alfabeta.

Syahyuni, D. (2018). Hubungan Antara Kinerja Karyawan Dengan Promosi Jabatan Pada Unit Taman Marga Satwa Ragunan Dinas Kehutanan Provinsi DKI Jakarta. Widya Cipta - Jurnal Sekretari Dan Manajemen, 2(1), 76$82 . \quad$ Retrieved from https://ejournal.bsi.ac.id/ejurnal/index.php/wid yacipta/article/view/2660/2037 